\title{
Benthic invertebrates collected by the RV 'Walther Herwig I and II' in the Southwestern Atlantic Ocean (1966-1978): a review of the Zoological Museum of Hamburg invertebrates collection
}

\author{
Alvar Carranza ${ }^{1,2,}$, Pablo Limongi $^{1}$ and Andreas Schmidt-Rhaesa ${ }^{3}$ \\ ${ }^{1}$ Departamento de Ecología y Gestión Ambiental, Centro Universitario Regional Este-Cure, Sede Maldonado, Maldonado, Uruguay. ${ }^{2}$ Área \\ Biodiversidad y Conservación, Museo Nacional de Historia Natural, C.C. 399, CP 11000, Montevideo, Uruguay. ${ }^{3}$ Zoologisches Museum, \\ Leibniz Institut für die Analyse des Biodiversitätswandels (LIB), Hamburg site Martin-Luther-King-Platz 3, 20146 - Hamburg, Germany. \\ ORCID Alvar Carranza (D) https://orcid.org/0000-0003-3016-7955
}

Marine and Fishery Sciences MAFIS

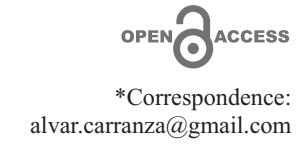

Received: 16 August 2021 Accepted: 17 September 2021

ISSN 2683-7595 (print) ISSN 2683-7951 (online)

https://ojs.inidep.edu.ar

Journal of the Instituto Nacional de Investigación y Desarrollo Pesquero (INIDEP)

under a Creative Commons AttributionNonCommercial-ShareAlike 4.0 International License
ABSTRACT. Digitally accessible Primary Biodiversity Data (PBD) are currently available through a number of web-based platforms. This information is allowing for a growing number of ecological, biodiversity informatics or conservation projects. Most of this information comes from Natural History Collections (NHC) worldwide. Despite well-known limitations, NHC data are particularly useful as a source of data on invertebrates, which comprise about $99 \%$ of animal life. However, a presumably very high amount of PBD is still not digitally accessible. Even the most important scientific collections in developed countries are not fully inventoried or digitally accessible. Furthermore, species determination rates remain alarmingly low for some collections, and most existing determinations probably should be retested. This is particularly true of expensive, difficultto-obtain deep-sea benthic samples. This paper reviews the database on material collected by the German RV 'Walther Herwig I and II' during 1966-1978 research cruises to the Southwestern Atlantic Ocean (SAO), stored in the invertebrate collection (invertebrates except Mollusca, Arthropoda and Annelida) of the Zoological Museum of Hamburg. We found that out of 3,305 records, at least 204 species were identified, $72 \%$ are still undetermined at species level and $65 \%$ at genus level. While sampling of more remote geographic areas and the use of a wider variety of sampling methods are still necessary, supporting the training of an army of taxonomists will be of paramount importance to overcome the daunting task of analyzing the huge number of samples. stored in museum collections. A community-wide effort is urgently needed to address this issue, and international cooperation must play a key role in this endeavor.

Key words: Oceanographic research, Southwestern Atlantic, benthic biodiversity, natural history, collections.

Invertebrados bentónicos recolectados por el BI "Walther Herwig I y II" en el Océano Atlántico Sudoccidental (1966-1978): una revisión de la colección de invertebrados del Museo Zoológico de Hamburgo

RESUMEN. Actualmente, los datos primarios de biodiversidad (DPB) accesibles digitalmente están disponibles a través de una serie de plataformas basadas en la web. Esta información ha posibilitado la generación de un número creciente de proyectos ecológicos, de informática de la biodiversidad o de conservación. La mayor parte de esta información proviene de las Colecciones de Historia Natural (CHN) de todo el mundo. A pesar de sus conocidas limitaciones, los datos de las CHN son particularmente útiles como fuente de datos sobre invertebrados, que comprenden alrededor del $99 \%$ de la vida animal. Sin embargo una cantidad presuntamente muy alta de DPB todavía no es accesible digitalmente. Incluso las colecciones científicas más importantes de los países desarrollados no se 
encuentran completamente inventariadas ni son accesibles digitalmente. Además, las tasas de determinación de especies siguen siendo alarmantemente bajas para algunas colecciones, y probablemente la mayoría de las determinaciones existentes deberían volver a analizarse. Esto resulta particularmente cierto con respecto a las muestras bentónicas de aguas profundas, caras y difíciles de obtener. Aquí revisamos la base de datos sobre el material recolectado por el BI alemán "Walther Herwig I y II" durante los cruceros de investigación entre 1966-1978 al Océano Atlántico Sudoccidental (SAO), almacenado en la colección de invertebrados (invertebrados excepto Mollusca, Arthropoda y Annelida) del Museo Zoológico de Hamburgo. Encontramos que de 3.305 registros, donde al menos 204 especies fueron identificadas, el 72\% todavía se encuentra sin determinar a nivel de especie y el 65\% a nivel de género. Si bien el muestreo de áreas geográficas más remotas y el uso de una mayor variedad de métodos de muestreo aún son necesarios, el apoyo a la capacitación de un ejército de taxónomos será de suma importancia para superar la abrumadora tarea de analizar la enorme cantidad de muestras almacenadas en las colecciones de los museos. Se necesita con urgencia un esfuerzo de toda la comunidad para abordar este problema, y la cooperación internacional debe desempeñar un papel clave en esta empresa.

Palabras clave: Investigación oceanográfica, Atlántico Sudoccidental, biodiversidad bentónica, historia natural, colecciones.

Natural history collections (NHC) worldwide harbour more than 3 billion of specimen records (Pyke and Ehrlich 2010). Multiple collectors over long periods of time have developed these ad hoc data sets which contain invaluable information on past and present biodiversity (Krishtalka and Humphrey 2000). Over the last years, this huge reservoir of information has been available since computing and the exchange of data through networks allowed solving the problems of digitizing, georeferencing and data distribution. Therefore, a large amount of museum data is, and many more will be, available to worldwide users.

The Southern Ocean has been the focus of oceanographic research since the late 17 th century, although it is only since the early 1960 s that international research in the area has begun to grow in importance. During this time, the scientific and technical systems of Argentina, Brazil and Uruguay were boosted by increasing connectivity due to the establishment of research networks and the development of bilateral programmes. Joint scientific efforts included cruises carried out by research vessels from Germany ('Walther Herwig I and II', 'Meteor'), USA ('Vema I' and 'Atlantis II'), Japan ('Kaiyo Maru', 'Orient Maru', 'Shinkai Maru'), Russia ('Evrika', 'Dimitry Stefanov') and Poland ('Professor Siedlecki'), triggering the development of regional ocean sciences (Angelescu and Sánchez 1995). In particular, bilateral research programmes in the second half of the 20th century (e.g. ArgentinaGermany exploration programmes) included four visits of the German RV Walther Herwig in 1966, 1968, 1970-1971 (Schmidt 1971) and 1978. The main objective of these research programmes, within the FAO Project of Fishery Development framework, was the survey and assessment of fishery resources of the Patagonian shelf (Angelescu and Sánchez 1995).

During the 'Walther Herwig I and II' (hereafter WH) cruises in the 1960s and 1970s, a wealth on material was collected in hundreds of stations in the Southwestern Atlantic Ocean (SAO). Most of these benthic invertebrate samples are currently stored in the Zoological Museum of Hamburg $(\mathrm{ZMH})$, whose nine research collections house more than ten million of scientific objects. Established in 1843 as the Hamburg Museum of Natural History, the Museum was later renamed as the State Institute of Zoology and then the ZMH, before it was finally incorporated into Universität Hamburg in 1969 (Köstering 2018). Recently, it fused with the Zoological Research Museum Koenig in Bonn to form the Leibniz Institute for the Analysis of Biodiversity Change (LIB). The material is separated into four collections: Invertebrates, Malacology, Annelida and Crustacea. This work analysed inventoried records housed in the Invertebrates Collection database of ZMH collected by the WH between 1966-1978. In addition, it analysed the taxonomic coverage, spatial informa- 
tion, including depth of the oceanographic stations. This will provide a comprehensive synthesis on the current status and potentialities of the Primary Biodiversity Data (PBD) associated with this particular collection, in order to encourage further similar research in NHC worldwide.

Research cruises herein analysed covered a large portion of the SAO off Brazil, Uruguay and Argentina. The Brazilian continental margin is strongly influenced by the western contour currents, the Brazil Current (BC) flowing southward and the Brazilian Northern Current (BNC) flowing northward. The $\mathrm{BC}$, which is shallowest between $15^{\circ} \mathrm{S}$ and $20^{\circ} \mathrm{S}$, transports saline and oligotrophic tropical waters, receiving additional contribution from the South Atlantic Central Waters (SACW), reaching a vertical extension of about $500 \mathrm{~m}$, and continues to flow southwards towards the Subtropical Convergence $\left(33^{\circ} \mathrm{S}-38^{\circ}\right.$ $\mathrm{S})$ where it merges with the Malvinas Current and then flows away from the coast to the east (Burone et al. 2021).

In the confluence zone, the Río de la Plata estuary represents the greatest freshwater inflow to the region, being one of the few geographical features (i.e., Valdés Peninsula, North Patagonic gulfs, and the Magallanes Strait) that influences water circulation at a regional scale (Miloslavich et al. 2011). Thus, the confluence of Malvinas and Brazil currents, together with the abundant terrestrial runoff of Río de la Plata, and the relatively shallow waters of the area, combine to produce a singular hydrographic system (Acha et al. 2008; Franco-Fraguas et al. 2014).

The Patagonian Shelf (PS) extends for about $5,649 \mathrm{~km}$ along the Atlantic coast of South America from northern Uruguay $\left(33^{\circ} 51^{\prime} 21^{\prime \prime} \mathrm{S}, 53^{\circ} 11^{\prime}\right.$ $\left.43^{\prime \prime} \mathrm{W}\right)$ to the southern tip of Argentina, bordering Chile ( $\left.54^{\circ} 55^{\prime} 39^{\prime \prime} \mathrm{S}, 64^{\circ} 52^{\prime} 12^{\prime \prime} \mathrm{W}\right)$. The area of the PS extends more than 3 million $\mathrm{km}^{2}$ in Uruguayan and Argentine territories and comprises coastal environments, the continental shelf itself, the slope, and ocean basins. Its continental shelf is generally up to $100 \mathrm{~m}$ in depth, and is the largest and one of the most productive ecosystems in the southern hemisphere (Acha et al. 2004; Miloslavich et al. 2011). Most of the PS is thus influenced by the Malvinas current, which originates in the Antarctic circumpolar current and carries a high nutrient load north along the Argentine and Uruguayan coasts. Nutrient-poor waters of the Brazil current meet the Malvinas current as it moves southward along the edge of the slope (Piola et al. 2010). In the confluence or transition zone (from $30^{\circ} \mathrm{S}$ to $46^{\circ} \mathrm{S}$ ), a series of oceanographic phenomena (eddies, marine fronts, etc.) allows for high biological production (Franco-Fraguas et al. 2014; Burone et al. 2021).

Thus, the geographical coverage of WH expeditions during the period 1966-1978 constitutes an invaluable sampling design, allowing lines of research and the analysis of biogeographic patterns at an enormous spatial realm, among others. For most taxonomic groups, however, species determination of benthic invertebrates needs thorough revision. The estimated number of taxonomists devoted to invertebrates in this region is low, and most research is focused on molluscs and crustaceans (Meier and Dikow 2004; Miloslavich et al. 2011).

We reviewed the $\mathrm{ZMH}$ invertebrates collection database and checked material from $\mathrm{WH}$ cruises from 1966 to 1978. The database was provided as several electronic spreadsheets, separated by taxonomic groups, often including two different spreadsheets for determined and undetermined material. We then analysed the number of records (i.e., assigned inventory number that may refer to a single or several individuals or colonies) and quantified the ratio of determined lower taxa (species and genus) to total samples. Assigned names were provided as is, since it was beyond our aim to review species concepts and/or nomenclatural issues. Due to different format of associated data, information on geographic coordinates of records was extracted (when available), very often by cross-checking the information provided against station lists and 
geographic references provided in other databases. Then, this georeferenced information was incorporated in a Geographic Information System, further detecting, fixing or deleting 'suspicious' coordinates due to error in data entering or handling. These records were mapped. Statistics on the spatial distribution of records were calculated, and particularly, an overview of the distribution of sampling effort associated with the Marine Ecoregions of the World (MEOWs) framework (Spalding et al. 2007) was provided. When available, depth-distribution of the samples was also registered.

The database herein assembled includes 3,305 records, comprising material from seven animal Phyla, namely Porifera, Cnidaria, Brachiopoda, Bryozoa, Echinodermata, Hemichordata and Chordata. Eighty six percent of records $(2,840)$ were georeferenced and associated with 8 MEOWs, representing Eastern Brazil, South-eastern Brazil, Rio Grande, Uruguay-Buenos Aires Shelf, Malvinas, Patagonian Shelf, North Patagonian Gulfs and Channels and Fjords of Southern Chile. Nearly $80 \%$ of records were concentrated in three MEOWs: Malvinas ( $\mathrm{N}=947)$, Patagonian Shelf $(\mathrm{N}=797)$ and Uruguay-Buenos Aires Shelf $(\mathrm{N}=458)$. Some 242 records fall outside the limits of MEOWs (i.e., $200 \mathrm{NM}$ ) and are thus referred to as collected from international waters (Figure 1). From the total, 2,853 records had associated depth data, showing an overall depth range from 1,400 to $33 \mathrm{~m}$. Nearly half of the records $(1,507)$ came from depths shallower than $200 \mathrm{~m}$.

Cnidaria was the best represented phylum, with 1,518 records, including hydrozoans (417 records) and anthozoans, comprising both hexacorallian (Antipatharia, Scleractinia, Corallimorpharia and Actiniaria) and octocorallians (Pennatularia and Alcyonacea). From the total number of records, 204 differently determined lower taxa were found, including determination of morphospecies (e.g., 'sp.' and 'sp. 1'), but more than $72 \%$ of the material is still undetermined (and some probably unsorted) at species level. Excluding morphos- pecies (i.e., not counting preliminary species determinations such as 'antarctica group', 'aff.' and 'cf.', etc.), only 163 species names are mentioned in the database. If we look at genus, $65 \%$ of records still lack determination (Table 1).

Groups with better taxonomic coverage include Anthozoa (Scleractinia, Corallimorpharia and Actiniaria), with all samples present in the database determined at species level. In particular, the high degree of taxonomic coverage in Actiniaria is due to the extensive work of Riemann-Zürneck (1973, 1975a, 1975b, 1978, 1980, 1986a, 1986b) on this material. However, there are 524 samples labelled as 'Anthozoa indet', and it is unclear whether all Scleractinia, Corallimorpharia and Actiniaria have been determined, or whether unidentified Anthozoa may include further records of these groups (Table 1). In this line, for four decades new species of Anthozoa have continued to be discovered from this material (Cairns 2012).

Amongst Echinodermata, Argentine researchers such as Bernasconi $(1972,1973)$ studied the ophiuroids, echinoids and asteroids from the 1966 cruise, and Hernández (1982) studied the holothuroids. According to Brogger and O'Hara (2015), WH ophiuroids from 1971 were studied by Bartsch (1982). In spite of this, virtually all Asteroidea and $96 \%$ of Ophiuroidea samples are undetermined, as are roughly half of Holothuroidea and Crinoidea. Thus, the current status of the taxonomic coverage of the Echinodermata is far from complete. This, however, does not reflect insufficient taxonomic knowledge, but rather a simple lack of time and/or opportunity to cross-check determinations made by Argentine researchers using essentially the same material. Voucher specimens seem to be deposited both in Argentina (Museo Argentino de Ciencias Naturales -MACN) and in the ZMH. For example, and concerning Ophiuroidea, Brogger and O'Hara reported material identified by Bernasconi (1973) from Walther Herwig Stn. 277 (1966), as Ophiacantha vivipara Ljungman, 1871 


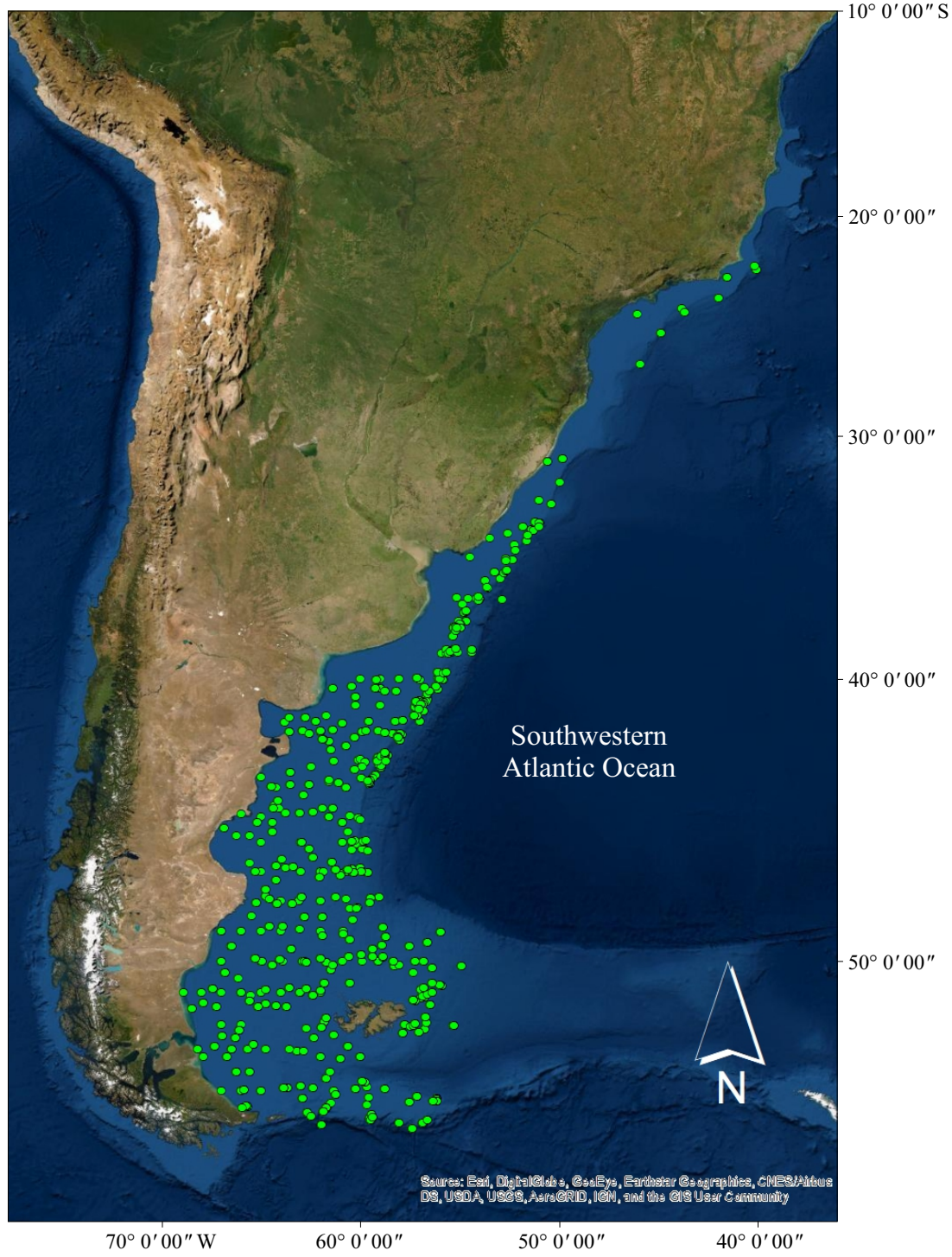

Figure 1. Surveyed stations by RV 'Walther Herwig I and II' in the Southwestern Atlantic Ocean from 1966 to 1978 . It must be noticed that since we were unable to retrieve location data for a number of stations, the map underestimates the spatial coverage of expeditions.

deposited in Argentina (MACN 27263). No Ophiuroids from this station are stored in the $\mathrm{ZMH}$, although there are Cnidarians and Bryozoans from the same station. However, material for $O$. vivipara is present in the $\mathrm{ZMH}$ collection, but labelled generically concerning the procedence (i.e., 'WH 1966, Patagonischer Schelf, 36² $2^{\prime}$ $54^{\circ} 51^{\prime} \mathrm{S} 54^{\circ} 01^{\prime}-63^{\circ} 51^{\prime} \mathrm{W}, 95-800 \mathrm{~m}$ ').
This database is thus a 'Gold mine' of unreported PBD, gathered using a standardised methodology and thus avoiding one of the most common problems of museum collections: a skewed abundance distribution due to collectors' potentially self-selecting underrepresented species over common ones (Guralnick and Cleve 2005). This collection further provides an excellent coverage 
Table 1. Summary of taxonomic coverage of samples stored in the Invertebrates II Collection of the Zoological Museum of Hamburg (ZMH). See text for details.

\begin{tabular}{|c|c|c|c|c|c|}
\hline Phylum & $\begin{array}{l}\text { Original taxon } \\
\text { name in the }\end{array}$ & $\begin{array}{c}\text { Total } \\
\text { samples }\end{array}$ & $\begin{array}{l}\text { Determined } \\
\text { (species) }\end{array}$ & $\begin{array}{l}\text { Determined } \\
\text { (genera) }\end{array}$ & $\begin{array}{c}\% \text { determined } \\
\text { (species) }\end{array}$ \\
\hline Brachiopoda & Brachiopoda & 104 & & & 0 \\
\hline Bryozoa & Bryozoa & 142 & & & 0 \\
\hline Chordata & Ascidiacea & 239 & 22 & & 9 \\
\hline Cnidaria & Anthozoa & 528 & & & 0 \\
\hline Cnidaria & Antipatharia & 3 & & & 0 \\
\hline Cnidaria & Pennatularia & 108 & 2 & 2 & 2 \\
\hline Cnidaria & Alcyonacea & 196 & 93 & 103 & 47 \\
\hline Cnidaria & Hydrozoa & 417 & 302 & 115 & 72 \\
\hline Cnidaria & Scleractinia & 92 & 92 & & 1 \\
\hline Cnidaria & Corallimorpharia & 2 & 2 & & 1 \\
\hline Cnidaria & Actiniaria & 172 & 172 & & 1 \\
\hline Echinodermata & Asteroidea & 530 & 1 & & 0 \\
\hline Echinodermata & Ophiuroidea & 137 & 6 & & 4 \\
\hline Echinodermata & Crinoidea & 9 & 4 & & 44 \\
\hline Echinodermata & Holothuroidea & 39 & 20 & 3 & 51 \\
\hline Echinodermata & Echinoidea & 211 & 208 & 3 & 99 \\
\hline Hemichordata & Pterobranchia & 17 & & & 0 \\
\hline Porifera & Porifera & 359 & & 19 & 0 \\
\hline Total & & 3,305 & 924 & 245 & 28 \\
\hline
\end{tabular}

from the study region, and it is hard to provide an exact figure of how costly it will be to implement the same sampling effort nowadays, but probably ranging in the order of tens of millions in current currency.

Once taxonomic work progresses, these data based on qualitative sampling can be rapidly assessed to produce biogeographic or macroecological studies. Meanwhile, entire regions may remain poorly or completely uninventoried, forcing conservation decisions to be based in incomplete data (Guralnick and Cleve 2005). Since there is an urgent need for the availability of this information, we must encourage support and funding for comprehensive inventories of marine invertebrates by trained researchers in taxonomy.
In this context, the decreasing number of taxonomists worldwide should be enhanced by means of global initiatives such as NSF-PEET and DIVERSITA. NSF-funded Planetary Biodiversity Inventories (PBI) targets the global coverage of a given Taxon, while the Partnerships for Enhancing Expertise in Taxonomy (PEET) focus in training the next generation of taxonomists. Yet even so, taxonomy seems to be facing the same chronic issues: inadequate funding and the lack of training and recruitment of taxonomists (Britz et al. 2020). This trend has to be quickly reversed. Otherwise, and with little or no specialists available worldwide for a number of taxonomic groups, we will not be able to exploit the information stored in NHCs. 


\section{ACKNOWLEDGEMENTS}

This work is part of the MSc. Thesis of P. Limongi (PEDECIBA-CAP). Alvar Carranza wishes to thank the $\mathrm{ZMH}$ staff, in particular Helma Roggenbuck, Dr Bernahard Hausdorf and Dr Martin Schwentner for their kind assistance during a sabbatical leave in Hamburg.

\section{REFERENCES}

Acha EM, Mianzán H, Guerrero R, Carreto J, Giberto D, Montoya N, Carignan M. 2008. An overview of physical and ecological processes in the Rio de la Plata Estuary. Cont Shelf Res. 28: 1579-1588. doi:10.1016/j.csr. 2007.01.031

Acha EM, Mianzán HW, Guerrero RA, FAVEro M, BAVA J. 2004. Marine fronts at the continental shelves of austral South America: physical and ecological processes. J Mar Systems. 44: 83-105. doi:10.1016/j.jmarsys.2003.09.005

ANGELESCU V, SÁNCHEZ RP. 1995. A century of oceanographic and fisheries exploration on the continental shelf off Argentina. Helgol Meeresunters. 49: 467-487. doi:10.1007/bf02368375

BARTSCH I. 1982. Ophiuroidea (Echinodermata) from the Patagonian shelf. Mitt Hambur Zool Mus Inst. 79: 211-250.

BERNASCONI I. 1972. Nuevas especies de Asteroidea: Bathybiaster herwigi sp. nov. (Astropectinidae) y Calyptraster vitreus sp. nov. (Pterasteridae). Physis. 31 (82): 9-14.

BERNASCONI I. 1973. Los equinodermos colectados por el "Walther Herwig" en el Atlántico Sudoeste. Rev Mus Argent Cienc Nat Bernardino Rivadavia Inst Nat Invest Cienc Nat (Argent) (Hidrobiol). 3 (3): 287-334.

Britz R, HunsDôRFER A, Fritz U. 2020 Funding, training, permits-the three big challenges of taxonomy. Megataxa. 1: 49-52.

Brogger MI, O'HARA TD. 2015. Revision of some ophiuroid records (Echinodermata: Ophiuroidea) from Argentina. Zootaxa. 3972: 432-440.

Burone L, Franco-Fraguas P, Carranza A, Calliari D, Michaelovitch de Mahiques M, Gómez M, Marin Y, Gutiérrez O, OrTega L. 2021. Physical drivers and dominant oceanographic processes on the Uruguayan margin (Southwestern Atlantic): a review and a conceptual model. J Mar Sci Eng. 9 (304): 1-29.

CAIRNS SD. 2012. New primnoid genus and species (Alcyonacea: Primnoidae) from the southwestern Atlantic. Proc Biol Soc Wash. 125 (2): 180-188.

Franco-Fraguas P, Burone L, Mahiques M, Ortega L, Urien C, Muñoz A, López G, Marín Y, Carranza A, Lahuerta N, DE Mello C. 2014. Hydrodynamic and geomorphological controls on surface sedimentation at the Subtropical Shelf Front/Brazil-Malvinas Confluence transition off Uruguay (Southwestern Atlantic Continental Margin). Mar Geol. 349: 24-36.

Guralnick R, Cleve JV. 2005. Strengths and weaknesses of museum and national survey data sets for predicting regional species richness: comparative and combined approaches. Divers Distrib. 11: 349-359.

HERNÁNDEZ DA. 1982. Holothuroidea des Sudwestatlantiks I. Die Trachythyone-Arten. Mitteilungen aus dem Hamburgischen Zoologischen Museum und Institut. 79: 251-261.

Köstering S. 2018. Ein Museum für Weltnatur. Die Geschichte des Naturhistorischen Museums in Hamburg. Abhandlungen des Naturwissenschaftlichen Vereins in Hamburg. 46. 343 p.

Krishtalka L, HuMPhrey PS. 2000. Can natural history museums capture the future? Bioscience. 50: 611-617.

Meier R, Dikow T. 2004. Significance of specimen databases from taxonomic revisions for estimating and mapping the global species 
diversity of invertebrates and repatriating reliable specimen data. Conserv Biol. 18: 478488.

Miloslavich P, Klein E, Díaz JM, Hernández CE, Bigatti G, Campos L, Artigas F, Castillo J, Penchaszadeh PE, Neill PE, et al. 2011. Marine biodiversity in the Atlantic and Pacific Coasts of South America: knowledge and gaps. PLoS ONE. 6 (1): e14631.

Piola AR, Martínez Avellaneda N, Guerrero RA, JARDON FP, PALMA ED, Romero SI. 2010. Malvinas-slope water intrusions on the northern Patagonia continental shelf. Ocean Sci. 6 (1): 345-359.

Pyke GH, Ehrlich PR. 2010. Biological collections and ecological/environmental research: a review, some observations and a look to the future. Biol Rev. 85: 247-266.

RIEMANN-ZÜRNECK K. 1973. Actiniaria of the Southwestern Atlantic Ocean. I. Hormathiidae. Helgol Wiss Meeresunters. 25: 273-325.

RIEMANN-ZÜRNECK K. 1975a. Actiniaria des Südwestatlantik III. Calliactis androgyna sp. n. (Hormathiidae). Veroff Institut Meeresforschung Bremerhaven. 15: 387-395.

RIEMANN-ZÜRNECK K. 1975b. Actiniaria des Südwestatlantik. II. Sagartiidae und Metridiidae. Helgol Wiss Meeresunters. 27, 70-95.
RiEMANN-ZÜRNECK K. 1978. Actiniaria des Südwestatlantik. IV. Actinostola crassicomis (Hertwig, 1882) mit einer Diskussion verwandter Arten. Veroff Institut Meeresforschung Bremerhaven. 17: 65-85.

RIEMANN-ZÜRNECK K. 1980. Actiniaria des südwestatlantik. V. Bolocera, Isotealia, Isosicyonis (Actiniidae). Mitteilungen aus dem Hamburgischen Zoologischen Museum und Institut. 77: 19-33.

RIEMANN-ZÜRNECK K. 1986a. Zur Biogeographie des Südwestatlantik mit besonderer Berücksichtigung der Seeanemonen (Coelenterata: Actiniaria). Helgol Meeresunters. 40: 91-149.

RIEMANN-ZÜRNECK K. 1986b. On the biogeography of the southwest Atlantic with special reference to the sea anemones (Coelenterata: Actiniaria). Helgol Meeresunters. 40: 91-149.

SCHMIDT U. 1971. Südamerikareise des FFS "Walther Herwig" - 1. Bericht über den Untersuchungsabschnitt Patagonienschelf. Informationen für die Fischwirtschaft. 18: 45-46.

Spalding MD, Fox HE, Allen GR, Davidson N, FERdaña ZA, Finlayson M, Halpern BS, Jorge MA, LOMBAnA A, Lourie SA, et al. 2007. Marine ecoregions of the world: a bioregionalization of coastal and shelf areas. BioScience. 57 (7): 573-583. 